\title{
ХРОНИКА
}

DOI: https://doi.org/10.17308/geology.2020.4/3132

ISSN 1609-0691

Поступила в редакцию: 01.11.2020

Принята к публикации: 01.12.2020

Опубликована онлайн: 18.12 .2020

Received: 01.11.2020

Accepted: 01.12.2019

Published online: 18.12 .2020

\section{К 90-летию со дня рождения Андрея Петровича Таркова}

\author{
А. И. Дубянский, Л. И. Надёжка, Т. Б. Силкина ${ }^{\varpi}$ \\ Воронежский государственный университет, \\ Университетская пл., 1, 394018, Воронеж, Российская Федерация
}

\section{To the $\mathbf{9 0}^{\text {th }}$ anniversary from the birth of Andrey P. Tarkov}

\author{
A. I. Dubyansky, L. I. Nadezhka, T. B. Silkina ${ }^{\bowtie}$ \\ Voronezh State University, 1 Universitetskaya pl., 394018, Voronezh, Russian Federation
}

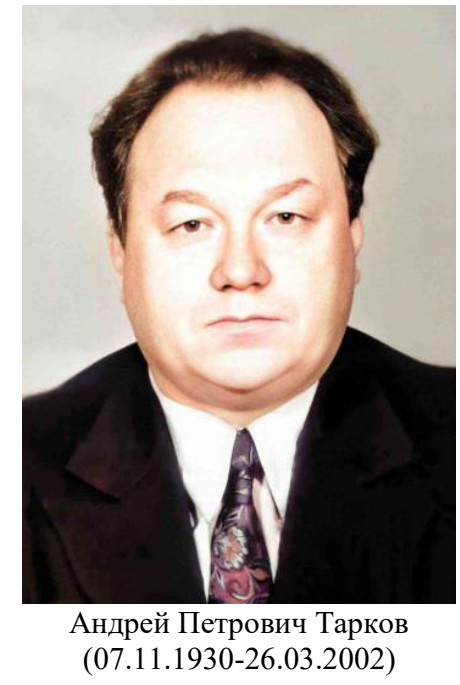

7 ноября 2020 года исполняется 90 лет со дня рождения Андрея Петровича Таркова - профессора, доктора геолого-минералогических наук, заслуженного работника высшей школы Российской Федерации, яркой личности, неординарного, блестящего организатора, учёного и прекрасного преподавателя.

После окончания геологического факультета Московского государственного университета в 1954 г.,
Андрей Петрович активно начал практическую деятельность в геолого-геофизических организациях Сибири. А после защиты кандидатской диссертации в 1959 году возглавил Дальневосточную группу геофизических партий ВНИИГеофизики.

К началу 60-х годов геофизические методы поисков и разведки полезных ископаемых стали весьма важной и неотъемлемой частью геологоразведочных работ. Занимаясь научно-производственной деятельностью на Дальнем Востоке, Андрей Петрович на практике почувствовал потребность в специалистах-геофизиках. Приехав в Воронеж в 1961 году, он первое время работал доцентом на кафедре разведочного дела Воронежского государственного университета. В это время геофизической специальности на геологическом факультете не было. Андрей Петрович, с присущей ему энергией, инициативой и талантом организатора начал работу по созданию кафедры геофизических методов поисков и разведки полезных ископаемых. Его активно поддерживали в то время ректор Борис Иванович Михантьев и член-корреспондент АН ССР Всеволод Владимирович Федынский. И в 1962 году на геологическом факультете Воронежского государственного университета была создана кафедра геофизических методов поисков и разведки полезных ископаемых. Андрей Петрович стал первым её заведую-

Контент доступен под лицензией Creative Commons Attribution 4.0 License.

The content is available under Creative Commons Attribution 4.0 License.

\footnotetext{
$\bowtie$ Силкина Татьяна Борисовна, e-mail: imperare.tatiana@ya.ru
} 


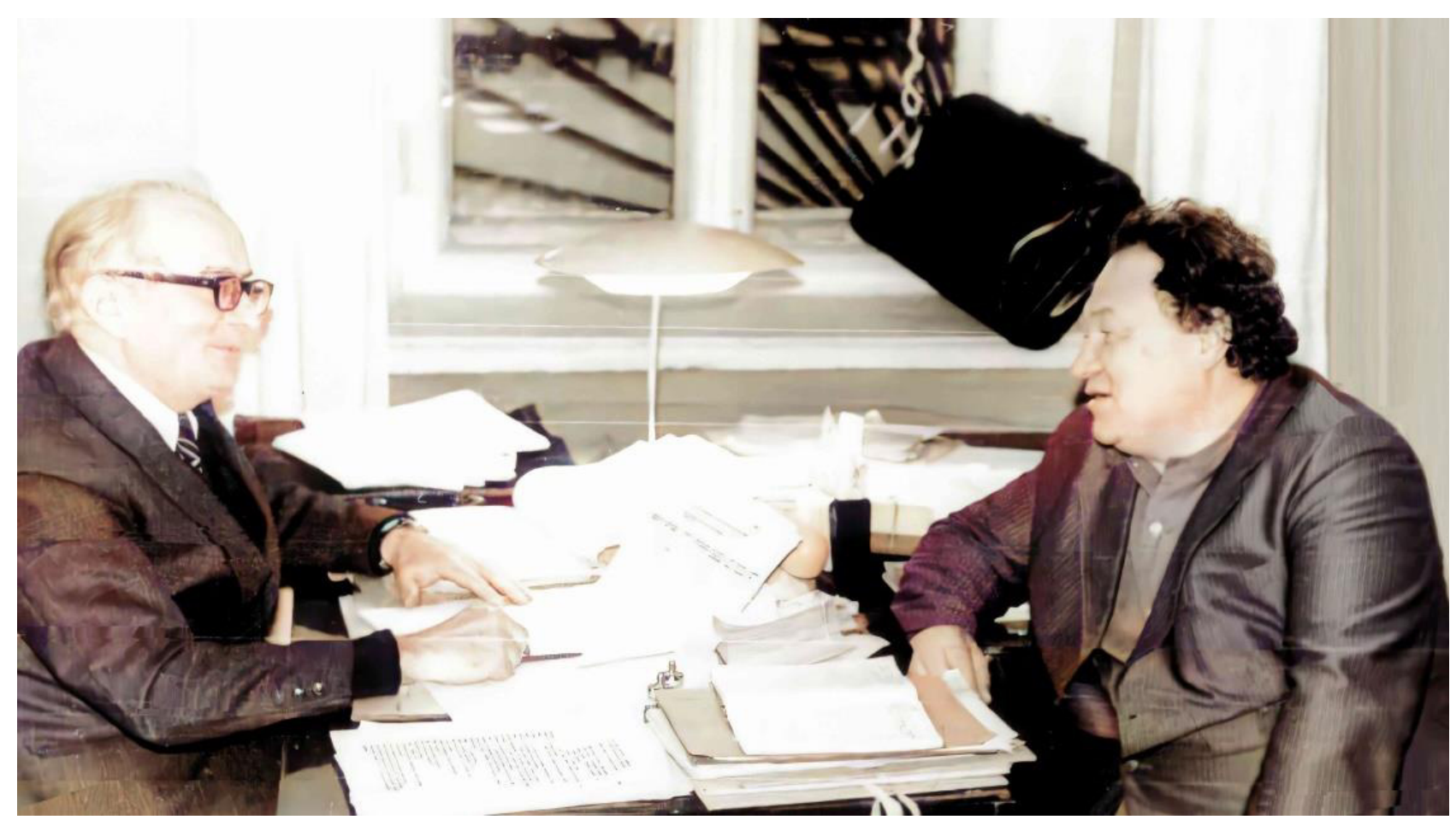

Андрей Петрович Тарков с Альбертом Карловичем Аузиным на кафедре, 1979 г.

щим. Ему принадлежит основная роль в подборе кадров высокой квалификации - преподавателей.

Как человек творческий, инициативный Андрей Петрович прекрасно понимал, что для успешной подготовки специалистов-геофизиков необходимы не только преподаватели высокой квалификации, но и современное материальное обеспечение, на базе которого можно было бы организовать учебный процесс. Он добивается оснащения кафедры лучшим на то время геофизическим оборудованием. Это оборудование несколько десятилетий служило базой для подготовки специалистов.

Постепенно кафедра развивалась. Андрей Петрович руководил кафедрой более 17 лет. Под его руководством кафедрой приём студентов был увеличен до 50 человек, 40 \% от общего приёма студентов на геологический факультет. Кафедра готовила студентов по двум специальностям: рудной и структурной.

Учёный, творчески мыслящий, Андрей Петрович за короткое время организовал, и длительное время поддерживал научные исследования по рудной сейсморазведке и взрывной сейсмологии в рамках госбюджетных и договорных тем.

В начале 70-х годов Андрей Петрович Тарков начал уникальные по задачам и масштабам исследования глубинного строения земной коры и верхней мантии Воронежского кристаллического массива комплексом геофизических и петрофизических методов. Благодаря этим исследованиям литосфера региона в настоящее время наиболее подробно изучена по сравнению с другими регионами Восточно-Европейской платформы.

Андрей Петрович обладал удивительной работоспособностью, неиссякаемым оптимизмом и вдохновением при выполнении всех исследований, заряжая энтузиазмом своих учеников, вовлекая их в научные поиски и изыскания.

Результаты научных исследований, выполненные под руководством А. П. Таркова, легли в основу двух докторских и 6 кандидатских диссертаций его учеников.

Он автор более 70 научных работ, в том числе, трёх монографий. В трудах XXIV и XXVII сессии МКГ опубликованы доклады А.П. Таркова по результатам интерпретации глубинных сейсмических исследований на территории ВКМ.

За активную научную, педагогическую и общественную работу в Воронежском государственном университете решением коллегии Министерства геологии СССР Андрей Петрович был награжден знаком «Отличник разведки недр», а также ему было присвоено почетное звание «Заслуженный работник высшей школы Российской Федерации».

В настоящее время идеи Андрея Петровича продолжают развиваться и совершенствоваться сотрудниками кафедры геофизики и лаборатории глубинного строения, геодинамики и сейсмического мониторинга Воронежского государственного университета, которая носит имя профессора Андрея Петровича Таркова. 
Для цитирования: Дубянский А. И., Надёжка Л. И., Силкина Т. Б.. К 90-летию со дня рождения Андрея Петровича Таркова // Вестник Воронежского государственного университета. Серия: Геология. 2020. №4. С. 94-96.

DOI: https://doi.org/10.17308/geology.2020.4/3132

Конфликт интересов: Авторы декларируют отсутствие явных и потенциальных конфликтов интересов, связанных с публикацией настоящей статьи.
For citation: Dubyansky A.I., Nadezhka L. I., Silkina T. B. To the $90^{\text {th }}$ anniversary from the birth of Andrey P. Tarkov. Vestnik Voronezhskogo gosudarstvennogo universiteta. Seriya: Geologiya $=$ Proceedings of Voronezh State University. Series: Geology, 2020, no. 4, pp. 94-96.

DOI: https://doi.org/10.17308/geology.2020.4/3132

Conflict of interests: The authors declare the absence of obvious and potential conflicts of interest related to the publication of this article.
Дубянский Александр Игоревич - к.г.-м.н., доцент кафедры геофизики, Воронежский государственный университет, Воронеж, Российская Федерация; E-mail: alex-dub-1942@ya.ru

Надёжка Людмила Ивановна - к.г.-м.н., доцент, заведующая лабораторией Глубинного строения, геодинамики и сейсмического мониторинга имени профессора А. П. Таркова, Воронежский государственный университет, Воронеж, Российская Федерация; E-mail: nadezhka_ssm@geophys.vsu.ru

Силкина Татьяна Борисовна - ведущий программист кафедры геофизики, Воронежский государственный университет, Воронеж, Российская Федерация;

E-mail: imperare.tatiana@ya.ru

Авторы прочитали и одобрили окончательный вариант рукописи.
Alexander I. Dubyansky - PhD in Geol-Min., Associate Professor, Department of Geophysics, Voronezh State University, Voronezh, Russian Federation; E-mail: alex-dub-1942@ya.ru

Lyudmila I. Nadezhka - PhD in Geol-Min., Head of the Laboratory of Deep Structure, Geodynamics and Seismic Monitoring named after Professor A. P. Tarkov, Voronezh State University, Voronezh, Russian Federation;

E-mail: nadezhka_ssm@geophys.vsu.ru

Tatiana B. Silkina - lead coder, Department of Geophysics, Voronezh State University, Voronezh, Russian Federation; E-mail: imperare.tatiana@ya.ru

The authors have read and approved the final manuscript. 